\title{
PENGARUH MODEL PEMBELAJARAN VISUAL AUDITORY KINESTETHIC BERNUANSA LINGKUNGAN TERHADAP KOMPETENSI PENGETAHUAN IPA
}

\author{
I Kadek Sastra Adi Merta', I Wayan Darsana², Ida Bagus Gede Surya Abadi \\ 1,2,3 Jurusan Pendidikan Dasar, Universitas Pendidikan Ganesha, Indonesia \\ e-mail: sastra.adi.merta@undiksha.ac.id, \\ iwayan.darsana@undiksha.ac.id,idabagusgedesurya.abadi@undiksha.ac.id
}

\begin{abstract}
ABSTRAK
Penelitian ini bertujuan untuk mengetahui perbedaan yang signifikan kompetensi pengetahuan IPA kelompok siswa yang dibelajarkan menggunakan model pembelajaran Visual Auditory Kinestethic bernuansa lingkungan dan kelompok siswa yang dibelajarkan menggunakan pembelajaran konvensional siswa kelas V SD Negeri Gugus Kolonel I Gusti Ngurah Rai Denpasar Utara Tahun Ajaran 2018/2019. Penelitian ini merupakan penelitian eksperimen semu dengan rancangan nonequivalent control group design. Populasi pada penelitian ini adalah seluruh siswa kelas V SD Negeri Gugus Kolonel I Gusti Ngurah Rai Denpasar Utara Tahun Ajaran 2018/2019 yang berjumlah 474 siswa. Penentuan sampel dalam penelitian menggunakan teknik random sampling dengan pengacakan kelas yang sudah ada, kemudian dilakukan pengudian untuk penentuan kelompok eksperimen dan kontrol sehingga kelas VA SD Negeri 6 Ubung yang berjumlah 34 siswa sebagai kelompok eksperimen dan kelas VA SD Negeri 4 Ubung yang berjumlah 42 siswa sebagai kelompok kontrol. Data kompetensi pengetahuan IPA siswa dikumpulkan dengan instrumen tes objektif pilihan ganda biasa sebanyak 25 soal yang sudah divalidasi. Nilai gain skor dinormalisasi dianalisis menggunakan uji-t. Hasil analisis uji-t menunjukkan nilai $t_{\text {hitung }}=5,448>t_{\text {tabel }}(a=0,05, d k=74)=2,000$ sehingga $\mathrm{H}_{0}$ ditolak dan $\mathrm{Ha}$ diterima. Sesuai dengan hasil tersebut dapat disimpulkan terdapat pengaruh yang signifikan model pembelajaran Visual Auditory Kinestethic bernuansa lingkungan terhadap kompetensi pengetahuan IPA siswa kelas V SD Negeri Gugus Kolonel I Gusti Ngurah Rai Denpasar Utara Tahun Ajaran 2018/2019. Untuk peneliti yang memiliki kesamaan variabel, hasil penelitian ini dapat dipergunakan sebagai kajian penelitian relevan.
\end{abstract}

Kata Kunci : visual auditory kinestethic, lingkungan, IPA

\section{Abstract}

This research aimed to know the significant difference of science competency between students taught by learning model Visual Auditory Kinestethic with enviromental nuance and students taught by conventional technique at 5 grades students of SD N Gugus Kolonel I Gusti Ngurah Rai Denpasar Utara year 2018/2019. This was a quasi-experimental research with non-equivalent control group design. The population was all 5 grades students at SD Negeri Gugus Kolonel I Gusti Ngurah Rai Denpasar Utara which consist of 474 students. Random sampling technique was use after randomize the class and using lottery to decide the experimental and control group. VA class of SD N 6 Ubung which consist of 34 siswa was chosen as experimental group and VA class of SD N 4 Ubung which consist of 42 students as control group. The data was collected using 25 items of common multiple choices which already valid. The score is analyze using $t$-test and show the score of $t_{\text {calculated }}=5,448>$ $t_{\text {table }}(a=0,05, d k=74)=2,000$. Hence, $H_{0}$ is rejecte and $H_{A}$ is accepte. From that result, it is conclude that there is a significant defference of science competency between students taught by VISUAL AUDITORY KINESTETHIC with enviromental nuance and students taught conventionaly on 5 grades students at SD N Gugus Kolonel I Gusti Ngurah Rai Denpasar Utara 2018/2019. For other researchers who have the same variabel, this can be a relevant reference.

Keywords : Visual Auditory Kinestethic, Environment, Science 


\section{Pendahuluan}

Pendidikan merupakan bagian yang sangat penting dalam proses pembangunan suatu bangsa dan negara, karena tanpa didukungnya pendidikan tidak mungkin pembangunan suatu bangsa dan negara dapat berkembang dengan baik. Kita dapat melihat contohnya yaitu perkembangan antara desa dengan kota, dimana kota bisa dianggap lebih berkembang dari pada desa dikarenakan sistem pembangunan yang dipimpin oleh orang-orang terpelajar. Pendidikan itu sebenarnya harus didapatkan oleh setiap lapisan masyarakat agar pembangunan suatu bangsa dan negara itu dapat berjalan dengan baik. Hal tersebut juga terlihat dalam UUD 1945 pasal 31 yang menyatakan bahwa setiap warga negara berhak mendapatkan pendidikan (Amandemen UUD 1945, Bab XIII tentang Pendidikan dan Kebudayaan). Pernyataan dalam pasal 31 itu sekaligus merupakan landasan dan jaminan bagi setiap warga negara Indonesia untuk memperoleh pendidikan tanpa membedakan suku, agama, dan golongan (Sirait, 2016).

Pendidikan adalah sarana penting untuk meningkatkan kualitas Sumber Daya Manusia (SDM) dalam menjamin keberlangsungan pembangunan suatu bangsa. Peningkatan kualitas SDM jauh lebih mendesak untuk segera direalisasikan terutama dalam menghadapi era persaingan global. Pendidikan dapat membangun masyarakat yang cerdas, damai, terbuka dan demokratis. Seperti yang tercantum dalam pasal 1 ayat 1 UU No. 20 Tahun 2003 tentang Sistem Pendidikan Nasional menyebutkan pendidikan merupakan usaha sadar dan terencana untuk mewujudkan suasana belajar dan proses pembelajaran agar siswa secara aktif mengembangkan potensi dirinya untuk memiliki kekuatan spritual keagamaan, pengendalian diri, kepribadian, kecerdasan, akhlak mulia, serta keterampilan yang diperlukan dirinya, masyarakat, bangsa dan negara. Menurut Soyomukti (2016:30) "pendidikan adalah pengajaran yang diselenggarakan di sekolah sebagai lembaga tempat mendidik (mengajar)". Pendidikan sangat erat kaitannya dengan pembelajaran, proses pembelajaran di sekolah dilaksanakan dengan berpedoman pada kurikulum. Menurut Pasal 1 ayat (19) Undang-undang Nomor 20 Tahun 2003 tentang sistem Pendidikan Nasional, "kurikulum adalah seperangkat rencana dan pengaturan mengenai tujuan, isi, dan bahan pelajaran serta cara yang digunakan sebagai pedoman penyelenggaraan kegiatan pembelajaran untuk mencapai pendidikan tertentu".

Pada saat ini, kurikulum yang berlaku pada sekolah dasar adalah kurikulum 2013. Pembelajaran yang digunakan pada Kurikulum 2013 adalah pembelajaran tematik. Pembelajaran tematik adalah pembelajaran yang menggunakan tema untuk mengaitkan beberapa mata pelajaran sehingga dapat memberikan pengalaman bermakna bagi siswa. Pada kurikulum 2013, pembelajarannya menggunakan pendekatan saintifik. Daryanto (2014:51) mengatakan bahwa pembelajaran dengan pendekatan saintifik adalah proses pembelajaran yang dirancang sedemikian rupa agar peserta didik secara aktif mengkonstruksi konsep, hukum atau prinsip melalui tahapan-tahapan mengamati (untuk mengidentifikasi masalah), merumuskan masalah, mengajukan atau merumuskan hipotesis, mengumpulkan data dengan berbagai teknik, menganalisis data, menarik kesimpulan dan mengkomunikasikan konsep, hukum atau prinsip yang "ditemukan".

Dalam kurikulum yang berorientasi pada pencapaian kompetensi, tujuan yang harus dicapai oleh siswa dirumuskan dalam bentuk kompetensi. "Dalam konteks pengembangan kurikulum, kompetensi merupakan perpaduan dari pengetahuan, keterampilan, nilai dan sikap yang direfleksikan dalam kebiasaan berpikir dan bertindak." (Sanjaya, 2016:70). Sedangkan menurut Yusuf (2015:263) "kompetensi merupakan perpaduan skill, tingkah laku dan pengetahuan serta nilai-nilai dasar yang dapat didemonstrasikan atau direfleksikan dalam kebiasaan dan kemampuan berpikir dan bertindak siswa yang dicapai melalui kegiatan mengajar yang bermakna dan penuh arti". Kompetensi yang harus dikuasai oleh peserta didik perlu dinyatakan sedemikian rupa agar dapat dinilai, sebagai wujud kompetensi pengetahuan peserta didik yang mengacu pada pengalaman langsung. Dalam kurikulum 2013, kompetensi adalah sesuatu yang sangat kompleks yang didalamnya mengandung banyak aspek (ranah), dimana aspek tersebut dinyatakan dalam rumusan kompetensi inti yang dinotasikan sebagai berikut (1) Kompetensi Inti-1 untuk kompetensi sikap spiritual, (2) 
Kompetensi Inti-2 untuk kompetensi sikap sosial, (3) Kompetensi Inti-3 untuk kompetensi pengetahuan, (4) Kompetensi Inti-4 untuk kompetensi keterampilan.

Kompetensi pengetahuan merupakan salah satu kompetensi yang tercantum dalam Kompetensi Inti-3 (KI-3) Kurikulum 2013 yang merupakan suatu perubahan perilaku seseorang yang dapat dilihat dari segi kemampuan pengetahuan setelah memperoleh pengalaman belajar. Kompetensi pengetahuan dapat dengan jelas mengukur kemampuan siswa dalam memahami dan menguasai isi dari suatu materi atau bahan pelajaran setelah memperoleh pengalaman belajar. "Pengetahuan adalah segala sesuatu yang diketahui manusia" (Wisudawati dan Sulistyowati, 2015:23). Menurut Sani (2014:47) "dimensi pengetahuan yang harus dimiliki oleh siswa SD hanya merupakan pengetahuan faktual dan pengetahuan konseptual. Dimensi pengetahuan (dimensi proses kognitif) faktual dan konseptual terdiri dari mengingat, memahami dan mengaplikasikan".

Pada Permendikbud Nomor 57 Tahun 2014, dalam kurikulum 2013 salah satu mata pelajaran kelompok A adalah IPA. Proses pelajaran IPA di sekolah dasar menggunakan bentuk pembelajaran tematik interatif yang artinya materi ajar dalam tematik integratif, disampaikan dalam bentuk tema-tema dan mengintegrasikan beberapa mata pelajaran pokok yakni IPS, Bahasa Indonesia, PPKn, IPA, Seni Budaya dan Prakarya (SBDP), serta Pendidikan Jasmani, Olahraga, dan Kesehatan (PJOK). Berbagai mata pelajaran diintegrasikan ke dalam satu tema dengan mengembangkan kompetensi sikap, pengetahuan, dan keterampilan. Materi IPA di SD kelas I sd III terintegrasi dalam mata pelajaran Bahasa Indonesia dan Pendidikan Jasmani olahraga dan Kesehatan. Pembelajaran dilakukan secara terpadu dalam tema dengan mata pelajaran lain. Untuk SD kelas IV sd VI, IPA menjadi mata pelajaran tersendiri namum pembelajaran dilakukan secara tematik terpadu.

Pada jenjang pendidikan dasar siswa dibelajarkan sejumlah mata pelajaran, salah satu diantaranya adalah IPA (Ilmu Pengetahuan Alam). Menurut Samatowa (2016:3) "IPA merupakan ilmu yang mempelajari peristiwa-peristiwa yang terjadi di alam ini. IPA membahas tentang gejala-gejala alam yang disusun secara sistematis yang didasarkan pada hasil percobaan dan pengamatan manusia". Proses pembelajaran di SD memberikan kesempatan kepada siswa untuk terlibat secara aktif dalam proses pembelajaran melalui kegiatan belajar secara nyata yang dapat memupuk rasa ingin tahu siswa. Keberhasilan pembelajaran IPA dapat dinilai dari keberhasilan siswa yang mengikuti kegiatan pembelajaran tersebut. Untuk mencapai tujuan pembelajaran yang telah ditentukan, guru harus kreatif dan inovatif dalam mengemas sebuah pembelajaran yang menarik sehingga membuat siswa semangat untuk belajar.

IPA memegang peran sangat penting dalam kehidupan manusia, hal ini disebabkan karena kehidupan kita sangat tergantung dari alam, zat terkandung di alam, dan segala jenis gejala yang terjadi di alam. Susanto (2013:167) menyatakan "Sains atau IPA adalah usaha manusia dalam memahami alam semesta melalui pengamatan yang tepat pada sasaran, serta menggunakan prosedur, dan dijelaskan dengan penalaran sehingga mendapatkan suatu kesimpulan". Lebih jelas lagi menurut Wisudawati dan Sulistyowati (2015:22) berpendapat bahwa "IPA merupakan rumpunan ilmu, memiliki karakteristik khusus yaitu mempelajari fenomena alam yang faktual (factual), baik berupa kenyataan (reality) atau kejadian (events) dan hubungan sebab-akibatnya".

Berdasarkan hal yang telah diuraikan di atas, dapat disimpulkan bahwa kompetensi pengetahuan IPA adalah pemahaman terhadap sejumlah konsep dan informasi mengenai muatan materi IPA yang harus dikuasai oleh peserta didik melalui kegiatan pembelajaran yang bermakna dan dinyatakan dalam rentang capaian/nilai tertentu.

Namun kondisi riil yang terjadi saat ini di sekolah dasar, penerapan pendekatan saintifik dalam proses pembelajaran tematik khususnya pengintegrasian yang memuat mata pelajaran IPA belum dapat terlaksana dengan optimal. Hal ini diketahui dari hasil wawancara dan observasi dari kepala sekolah dan wali kelas $V$ masing-masing SD Negeri yang terdapat pada Gugus Kolonel I Gusti Ngurah Rai Denpasar Utara pada hari Senin tanggal 14 Januari 2019 sampai Sabtu tanggal 19 Januari 2019. Permasalahan terletak pada partisipasi siswa yang kurang, beberapa siswa kurang aktif dalam proses pembelajaran sehingga 
pembelajaran menjadi cenderung monoton. Pembelajaran cenderung monoton karena penerapan model pembelajaran yang kurang bervariasi dan memperhatikan karakteristik siswa. Dalam proses pembelajaran semua peserta didik dalam satu kelas dianggap memiliki kebutuhan dan kemampuan yang sama sehingga semua siswa diperlakukan dengan cara yang sama. Suasana belajar yang demikian akan menyebabkan pembelajaran kurang bermakna bagi siswa sehingga konsep yang diperoleh belum dapat diaplikasikan dalam kehidupan sehari-hari dengan tepat. Siswa menjadi tidak dapat secara aktif untuk mengkonstruksi pengetahuannya yang berpengaruh pada kurangnya kompetensi pengetahuan IPA yang dimiliki siswa. Hal ini dapat dilihat dari rata-rata nilai ulangan akhir semester ganjil pada kompetensi pengetahuan IPA tahun ajaran 2018/2019, hanya $71 \%$ atau 337 siswa dari 474 siswa yang mampu memenuhi Standar Kriteria Minimal (KKM) sedangkan 28,9\% atau 137 siswa dari 474 siswa masih belum memenuhi KKM yang ditetapkan sekolah masing-masing. Dari hasil tersebut dapat dilihat bahwa belum optimalnya kompetensi pengetahuan IPA sehingga masih ada siswa yang belum memenuhi KKM yang ditetapakan. Maka dari itu, diperlukan komponen-komponen lain untuk membantu memperlancar proses pembelajaran IPA agar mempermudah mencapai tujuan pembelajaran yang diinginkan. Cara yang dapat dilakukan oleh pendidik adalah dengan memilih model yang tepat serta sesuai dengan karakteristik siswa dan sesuai dengan lingkungan siswa. Sebagai langkah dalam menciptakan pembelajaran yang inovatif, bermakna dan memperhatikan karakteristik semua siswa, salah satu model pembelajaran yang dapat digunakan yaitu dengan menerapkan model pembelajaran Visual Auditory Kinestethic. Mengkolaborasikan model pembelajaran Visual Auditory Kinestethic dengan lingkungan menjadi semakin efektif, karena dengan lingkungan dapat memberikan pengalaman belajar bermakna yang tidak mudah dilupakan.

Dalam Huda $(2018,287)$ "tiga modalitas pembelajaran ini pertama kali dikembangkan oleh Neil Fleming untuk memajukan preferensi individu dalam proses belajarnya". Menurut Kardiyasa dalam E-Journalnya (2016) menyatakan bahwa, tipe belajar visual (Visual Learners) menitikberatkan pada ketajaman penglihatan. Tipe belajar Auditory (Auditory Learners) mengandalkan pada pendengaran untuk bisa memahami dan mengingatnya. Tipe belajar Kinestethic ( Kinesthetic Learners) mengharuskan individu yang bersangkutan menyentuh sesuatu yang memberikan informasi tertentu agar ia bisa mengingatnya. Menurut Ngalimun (2011: 235), mengatakan bahwa "model pembelajaran ini akan efektif dengan memperhatikan ketiga hal, dengan perkataan lain memanfaatkan potensi siswa yang telah dimilikinya dengan melatih dan mengembangkannya". Pembelajaran dengan model ini mementingkan pengalaman belajar secara langsung dan menyenangkan bagi siswa. Deporter dkk dalam (Shoimin, 2014: 226) menyatakan "pengalaman belajar secara langsung dengan cara belajar dengan mengingat (visual), belajar dengan mendengar (auditory), dan belajar dengan gerak dan emosi (kinestethic)". Meskipun ketiga modalitas tersebut hampir semuanya dimiliki oleh setiap orang, tetapi hampir semua dari mereka selalu cenderung pada salah satu di antara ketiganya. Ketiga modalitas ini digunakan untuk pembelajaran, pemrosesan, dan komunikasi. Bahkan, beberapa orang tidak hanya cenderung pada satu modalitas saja, mereka biasa memanfaatkan kombinasi modalitas tertentu untuk meningkatkan kemampuan belajar. Menurut Huda (2018), menyatakan Visual Auditory Kinestethic sebagai berikut, (1) Visual, modalitas visual mengakses citra visual yang diciptakan maupun diingat, seperti warna, hubungan ruang, potret mental, dan gambar. Seorang siswa yang visual sangat mungkin memiliki ciri-ciri sebagai berikut (a) teratur, memperhatikan segala sesuatu dan menjaga penampilan, (b) mengingat dengan gambar, lebih suka membaca daripada dibacakan, dan (c) membutuhkan gambaran dan tujuan yang menyeluruh untuk bisa menangkap detail atau menangkap apa yang dilihat. (2) Auditory, modalitas mengakses segala jenis bunyi dan kata yang diciptakan maupun yang diingat, seperti musik, nada, irama, rima, dialog internal, dan suara. Seorang siswa yang sangat auditorys dapat dicirikan sebagai berikut (a) perhatiannya mudah terpecah, (b) berbicara dengan pola berirama, (c) belajar dengan cara mendengarkan, dan (d) berdialog secara internal dan eksternal. (3) Kinestethic, modalitas ini mengakses segala gerak dan emosi yang diciptakan maupun diingat, seperti gerakan, koordinasi, irama, tanggapan emosional, 
dan kenyamanan fisik. Seorang siswa yang cenderung kinestethic dapat dicirikan sebagai berikut (a) menyentuh orang yang berdiri berdekatan, banyak gerak, (b) belajar sambal bekerja, menunjukkan tulisan saat membaca, menanggapi secara fisik, dan (c) mengingat sambil berjalan dan melihat. Jadi berdasarkan paparan di atas dapat disimpulkan bahwa model pembelajaran Visual Auditory Kinestethic adalah model pembelajaran yang memanfaatkan potensi siswa yang telah dimilikinya dengan melatih penglihatan (visual), pendengaran (auditory), dan gerak (kinestethic).

Sintaks pembelajaran Visual Auditory Kinestethic ada empat fase yaitu Fase 1 tahap persiapan, pada kegiatan pendahuluan guru memberikan motivasi untuk membangkitkan minat siswa dalam belajar, memberikan perasaan positif mengenai pengalaman belajar yang akan datang kepada siswa, dan menempatkan mereka dalam situasi optimal untuk menjadikan siswa lebih siap dalam menerima pelajaran. Fase 2 tahap penyampaian, pada kegiatan inti guru mengarahkan siswa untuk menemukan materi pelajaran yang baru secara mandiri, menyenangkan, relevan, melibatkan pancaindra, yang sesuai dengan gaya belajar Visual Auditory Kinestethic, tahap ini bisa disebut eksplorasi. Fase 3 ada tahap pelatihan, pada tahap pelatihan guru membantu siswa untuk mengintegrasi dan menyerap pengetahuan serta keterampilan baru dengan berbagai cara yang disesuaikan dengan gaya belajar Visual Auditory Kinestethic. Fase 4 adalah tahap mempresentasikan hasil, tahap penampilan hasil merupakan tahap seorang guru membantu siswa dalam menerapkan dan mempeluas pengetahuan maupun keterampilan baru yang mereka dapatkan pada kegiatan belajar sehingga kompetensi pengetahuan mengalami peningkatan.

Penerapan sebuah model pembelajaran dalam proses belajar mengajar di kelas memberikan hasil yang lebih maksimal jika dikombinasikan dengan lingkungan. Dalam penelitian ini, model pembelajaran Visual Auditory Kinestethic dikombinasikan dengan lingkungan. Siswa dibelajarakan menggunakan model pembelajaran Visual Auditory Kinestethic dengan suasana lingkungan sekitar. "Pemanfaatan lingkungan untuk menyajikan pembelajaran dapat memicu semangat dan motivasi siswa dalam proses pembelajaran sehingga dapat mencapai tujuan pembelajaran secara optimal" (Ardiani, 2014). Hal ini dikarenakan dalam pembelajaran siswa selalu berinteraksi dan tidak terlepas dari lingkungan. Dengan menggunakan lingkungan sebagai suasana pembelajaran lebih bermakna dan bernilai, sebab para siswa dihadapkan dengan peristiwa dan keadaan yang sebenarnya, keadaan yang lebih alami sehingga lebih nyata, dan lebih faktual. Menurut Anitah (2008:6.52) "lingkungan itu merupakan kesatuan ruang dengan semua benda dan keadaan makhluk hidup termasuk di dalamnya manusia dan perilakunya serta makhluk hidup lainnya. Lingkungan itu terdiri dari unsur-unsur biotik (makhluk hidup), abiotik (benda mati), dan budaya manusia". Menurut Uno dan Nurdin (2012:137) "lingkungan merupakan sumber belajar yang paling efektif dan efisien serta tidak memerlukan biaya yang besar dalam meningkatkan motivasi peserta didik". Lingkungan menyediakan berbagai hal yang dapat menjadi bahan pembelajaran. Lingkungan alam, sosial dan budaya di sekitar sekolah merupakan sumber daya yang sangat kaya untuk dijadikan bahan belajar siswa.

Pengembangan program pendidikan lingkungan sekolah diawali dengan mengidentifikasi pengetahuan, perilaku, dan keterampilan apa yang perlu dipelajari oleh siswa. Lingkungan sekolah memiliki keterkaitan baik langsung maupun tidak langsung dengan pembelajaran. Salah satu pemanfaatan lingkungan di sekolah adalah dengan pengaturan lingkungan kelas, pengaturan kelas yang baik menumbuhkan semangat dan motivasi siswa sehingga dapat mewujudkan tujuan pembelajaran. Selain penggunaan lingkungan kelas, belajar di luar kelas dan memanfaatkan lingkungan sekitar mampu menggugah semangat belajar siswa dan menunjang tercapainya tujuan pembelajaran yang maksimal. "Belajar di luar kelas bisa lebih menumbuhkan keaktifan jiwa raga siswa" (Setiawan,2011:6.30). Melalui keaktifan, mereka mampu mengolah kesan pengamatan menjadi pengetahuan. Keaktifan juga mendorong siswa untuk berinteraksi dengan lingkungan sehingga merupakan pengalaman langsung dengan lingkungan.

Semua mata pelajaran termasuk IImu Pengetahuan Alam dan lingkungan memiliki keterkaitan seperti pada aspek manusia, kebiasaan hidup, dan lingkungan hidup. Dalam pembelajaran IPA siswa dituntut membangun pengetahuan, keterampilan, dan sikap terkait 
dengan pengetahuan alam sekitar sesuai pengalamannya, dan mengaplikasikannya kembali dalam kehidupan sehari-hari. Oleh karenanya, dengan menggunakan lingkungan atau apa yang terdapat di sekitar siswa dalam proses pembelajaran, dapat memudahkan siswa dalam memahami konsep materi dan membangun pengetahuannya sendiri.

\section{Metode}

Jenis penelitian yang dilakukan dalam penelitian ini adalah penelitian kuantitatif dengan desain eksperimen yaitu quasi eksperiment (Eksperimen Semu) dengan alasan tidak semua karakteristik dan kondisi eksperimen dapat diatur dan dikontol secara ketat seperti halnya dalam penelitian eksperimen murni (true experiment). Desain yang digunakan yaitu melibatkan dua kelompok kelas, yaitu kelompok kelas pertama sebagai kelas eksperimen yang mendapatkan perlakuan khusus dengan menggunakan model pembelajaran Visual Auditory Kinestethic bernuansa lingkungan dan kelompok kelas kedua sebagai kelas kontrol menggunakan pembelajaran konvensional. Rancangan eksperimen semu yang digunakan dalam penelitian ini adalah Nonequivalent Control Group Design.

\begin{tabular}{|lcc|}
\hline $\mathrm{O}_{1}$ & $\mathrm{X}$ & $\mathrm{O}_{2}$ \\
\hdashline $\mathrm{O}_{3}$ & & $\mathrm{O}_{4}$ \\
\hline
\end{tabular}

Gambar 1. Rancangan non-equivalent control group design

(Sumber : Sugiyono,2017:79)

Keterangan :

$\mathrm{O}_{1} \quad$ : Pre-test pada kelompok eksperimen

$\mathrm{O}_{2} \quad$ : Post-test pada kelompok eksperimen

$\mathrm{O}_{3} \quad$ : Pre-test pada kelompok kontrol

$\mathrm{O}_{4} \quad$ : Post-test pada kelompok kontrol

X : Perlakuan pada kelompok eksperimen

Pre test diberikan untuk kelompok eksperimen dan kelompok kontrol. Setelah memberikan perlakuan, yaitu dengan memberikan model pembelajaran Visual Auditory Kinestethic bernuansa lingkungan kepada kelompok eksperimen sedangkan di kelas kontrol diberikan pembelajaran dengan pendekatan saintifik. Setelah diberikan perlakuan, data hasil kompetensi pengetahuan IPA diuji dengan membandingkan skor perolehan (gain score) antara pre test dan post test. Penelitian ini terdiri dari 3 tahapan yaitu tahap persiapan eksperimen, tahap pelaksanaan eksperimen, dan tahap akhir eksperimen.

Populasi pada penelitian ini adalah seluruh siswa Kelas V SD Negeri Gugus Kolonel I Gusti Ngurah Rai Denpasar Utara Tahun Ajaran 2018/2019 yang berjumlah 474 siswa. Penentukan sampel menggunakan teknik sampling yaitu Simple Random Sampling. Teknik sampel ini dalam penarikan sampel menggunakan teknik random atau mengacak yang akan memberikan kesempatan kepada semua populasi untuk dapat diipilih menjadi sampel. Hasil pengundian diperoleh Kelas VA SD Negeri 4 Ubung dan Kelas VA SD Negeri 6 Ubung, selanjutnya diuji kesetaraannya dengan menggunakan uji-t yang terlebih dahulu data dari kedua kelompok sudah memenuhi uji prasyarat normalitas sebaran data dan mohogenitas varians.

Berdasarkan hasil uji-t yang dilakukan diperoleh bahwa kedua kelompok tersebut setara dengan hasil analisis menunjukkan nilai $t_{\text {hitung }}=0,411$, untuk $d k=\left(n_{1}+n_{2}\right)-2=74$ dengan taraf signifikansi $5 \%$ diperoleh $t_{\text {tabel }}=2,000$ sehingga $t_{\text {hitung }}<t_{\text {tabel }}$ maka $H_{0}$ diterima sehingga kedua kelompok setara. Selanjutnya diundi untuk menentukan kelompok eksperimen dan kelompok kontrol, sehingga didapat Kelas VA SD Negeri 6 Ubung sebagai kelompok eksperimen dan Kelas VA SD Negeri 4 Ubung sebagai kelompok kontrol.

Ada dua validitas terkait dengan penelitian yang dilakukan, yaitu validitas internal dan validitas eksternal. Validitas internal bersumber dari pelaksanaan penelitian itu sendiri, 
sedangkan validitas eksternal bersumber dari luar penelitian yang dilakukan. Validitas internal dalam penelitian ini dapat berupa sejarah, kematangan, instrumentasi, mortalitas dan seleksi kelompok. Keterbatasan yang ada berdasarkan sejarah dapat dikendalikan dengan cara menggunakan kelompok kontrol atau kendali yang dapat diharapkan memiliki pengalaman eksternal yang sama selama pelaksanaan perlakuan seperti pada kelompok eksperimen. Untuk mengatasi faktor kematangan peneliti melakukan penelitian dengan menggunakan kelompok kontrol yang memiliki kesamaan pengalaman kematangan. Faktor instrumentasi diatasi dengan memberikan tes yang sesuai dengan pelaksanaan perlakuan. Cara yang dapat digunakan untuk mengatasi regresi statistik yaitu dengan menghindari pemilihan subjek yang memiliki skor ekstrim dan tidak dilibatkan sebagai kelompok subjek penelitian. Menghindari adanya masalah yang diakibatkan oleh mortalitas eksperimental, maka perlu membuat kelompok yang lebih besar mengambil langkah-langkah untuk menjamin representatif kelompok, dan berupaya menindak lanjuti adanya ketidakseimbangan kelompok karena subjek yang mangkir atau tidak terlibat penuh dari perlakuan dan sebagainya. Cara yang dapat dilakukan untuk mengatasi seleksi kelompok yaitu dengan memberikan pre test kepada kedua kelompok yang menjadi sampel penelitian untuk menguji kesetaraan kelompok tersebut. Selain faktor internal, ada faktor lain yang bersifat eksternal yang memiliki pengaruh pada hasil penelitiannya yaitu validitas eksternal. Pengendalian terhadap ancaman tersebut dilakukan dengan membatasi penelitian pada kelas V SD Negeri Gugus Kolonel I Gusti Ngurah Rai Denpasar Utara Tahun Ajaran 2018/2019. Selain itu untuk mengendalikan ancaman ini juga dapat dilakukan dengan pemilihan anggota sampel secara acak untuk mewakili populasi.

Data yang dikumpulkan dalam penelitian ini adalah data kompetensi pengetahuan IPA siswa kelas V SD Negeri Gugus Kolonel I Gusti Ngurah Rai Denpasar Utara Tahun Ajaran 2018/2019. Menurut Setyosari (2015:247), "Prosedur pengumpulan data ini menuturkan bagaimana data penelitian itu diperoleh". Pada penelitian ini, metode pengumpulan data yang digunakan adalah metode tes. Tes adalah alat yang digunakan untuk mengukur pengetahuan atau pemahaman anak terhadap materi yang telah diberikan. Tes yang dipergunakan berupa tes objektif pilihan ganda biasa dan telah diuji validitas, daya pembeda, indeks kesukaran dan reliabilitas sehingga didapatkan 25 butir soal yang valid.

Data dalam penelitian ini dianalisis menggunakan statistic deskriptif dan inferensial. Data yang dianalisis adalah data gain skor yang dinormalisasikan dari hasil pre test dan hasil post test. Rumus untuk menghitung gain skor dinormalisasi adalah sebagai berikut.

$$
\text { Gn }=\left[\frac{\text { Spost }- \text { Spre }}{\text { Smax }- \text { Spre }}\right]
$$

(Agung, 2014:145)

Keterangan :

Gn = Gain Skor

Spost $=$ Skor post test

Spre = Skor pre test

Smax = Skor maksimal ideal

"Statistik deskriptif adalah statistik yang digunakan untuk menganalisis data dengan cara mendeskripsikan atau menggambarkan data yang telah terkumpul sebagaimana adanya tanpa bermaksud membuat kesimpulan yang berlaku untuk umum atau generalisasi" (Sugiyono, 2017:147). Teknik analisis dengan data kuantitatif dapat menggunakan teknik statistik deskriptif diantaranya menentukan nilai rerata (mean), simpangan baku, dan varians. Statistik inferensial adalah "teknik statistik yang digunakan untuk menganalisis data sampel dan hasilnya diberlakukan untuk populasi" (Sugiyono, 2017:148). Sebelum dilakukan uji hipotesis dengan statistik inferensial menggunakan statistik parametrik, data yang akan dianalisis harus memenuhi beberapa prasyarat yaitu uji normalitas sebaran data dan uji homogenitas varians.

Uji Normalitas dilakukan untuk mengetahui apakah sebaran data kompetensi pengetahuan IPA siswa masing-masing kelompok berdistribusi normal atau tidak sehingga dapat menentukan teknik analisis datanya. Menghitung uji normalitas dalam penelitian ini 
menggunakan uji Kolmogorov-Smirnov. Kriteria pengujian adalah apabila nilai maksimum $\left|\mathrm{F}_{\mathrm{T}}-\mathrm{F}_{\mathrm{S}}\right| \leq$ nilai tabel Kolmogorov-Smirnov, maka data berdistribusi normal. Sebaliknya jika nilai maksimum $\left|\mathrm{F}_{\mathrm{T}}-\mathrm{F}_{\mathrm{S}}\right|>$ nilai tabel Kolmogorov-Smirnov, maka data tidak berdistribusi normal. Sedangkan untuk Uji homogenitas dilakukan untuk menunjukkan bahwa pengaruh yang terjadi pada uji hipotesis benar-benar terjadi akibat adanya pengaruh antar kelompok, bukan sebagai akibat pengaruh dalam kelompok. Uji homogenitas varians yang digunakan adalah uji Fisher $(F)$. Kriteria pengujian untuk mengetahui data yang mempunyai varians yang homogen yaitu, jika $F_{\text {hit }}<F_{\text {tabel }}$ maka sampel homogen. Pengujian dilakukan pada taraf signifikansi $5 \%$ dengan derajat kebebasan untuk pembilang $n_{1}-1$ dan derajat kebebasan untuk penyebut $n_{2}-1$.

Data yang telah diuji normalitas dan homogenitasnya selanjutnya dilakukan uji hipotesisnya. Uji hipotesis yang dilakukan dalam penelitian ini menggunakan analisis uji-t dengan taraf signifikansi $5 \%$. Uji Hipotesis menggunakan uji-t dengan rumus polled varians. Rumus uji-t dengan rumus polled varians digunakan dengan jumlah anggota sampel sama $n_{1}$ $\neq \mathrm{n}_{2}$ dan varians homogen. Dengan kriteria jika harga $t_{\text {hitung }} \leq t_{\text {tabel }}$, maka $\mathrm{H}_{\mathrm{o}}$ diterima dan $\mathrm{H}_{\mathrm{a}}$ ditolak, dan jika harga $t_{\text {hitung }}>t_{\text {tabel }}$ maka $\mathrm{H}_{0}$ ditolak dan $\mathrm{H}_{\mathrm{a}}$ diterima. Pada taraf signifikansi $5 \%$ dengan $\mathrm{dk}=\mathrm{n}_{1}+\mathrm{n}_{2}-2$.

\section{Hasil dan Pembahasan}

Objek pada penelitian ini adalah kompetensi pengetahuan IPA. Data yang dianalisis pada penelitian ini yaitu nilai gain skor dinormalisasi kompetensi pengetahuan IPA kelompok eksperimen dan nilai gain skor dinormalisasi kompetensi pengetahuan IPA kelompok kontrol. Mendeskripsikan data gain skor dinormalisasi kelompok eksperimen dilakukan dengan mencari Mean, Standar Deviasi, dan Varians dengan hasil sebagai berikut.

Tabel 1. Deskripsi data gain skor kelompok eksperimen

\begin{tabular}{ccc}
\hline Mean & Standar Deviasi & Varians \\
\hline 0,501 & 0,109 & 0,012 \\
\hline
\end{tabular}

Selanjutnya distribusi frekuensi ganda kompetensi pengetahuan IPA siswa kelompok eksperimen dapat disajikan menggunakan grafik histogram dengan bantuan IBM SPSS Statistics Versi 19 sebagai berikut.

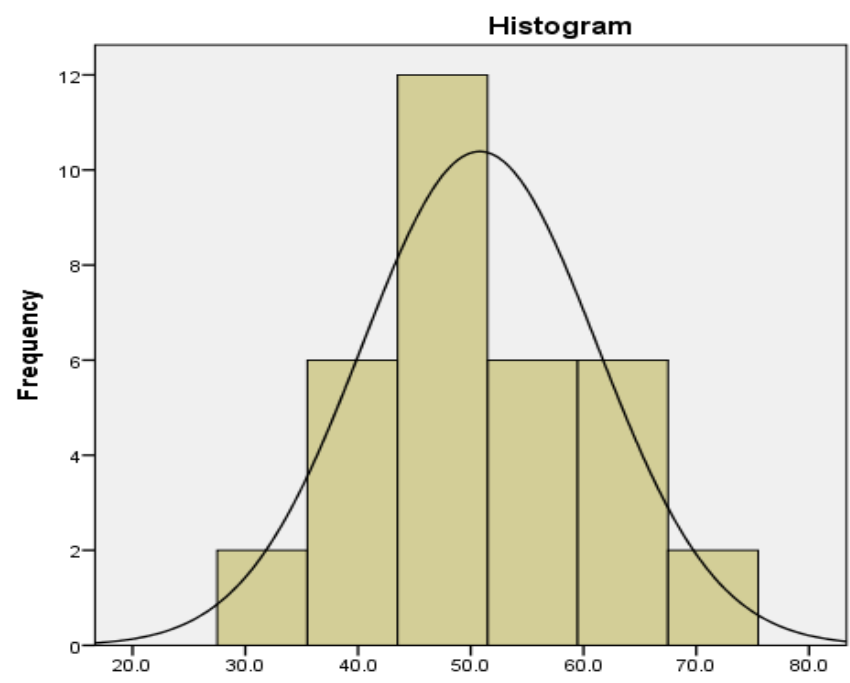

Gambar 2. Histogram gain skor dinormalisasi kompetensi pengetahuan IPA siswa kelompok eksperimen 
Mendeskripsikan data gain skor dinormalisasi kelompok kontrol dengan mencari Mean, Standar Deviasi, dan Varians dengan hasil sebagai berikut.

Tabel 3. Deskripsi data gain skor kelompok kontrol

\begin{tabular}{ccc}
\hline Mean & Standar Deviasi & Varians \\
\hline 0,343 & 0,138 & 0,019 \\
\hline
\end{tabular}

Selanjutnya distribusi frekuensi ganda kompetensi pengetahuan IPA siswa kelompok kontrol dapat disajikan menggunakan grafik histogram dengan bantuan IBM SPSS Statistik Versi 19 sebagai berikut.

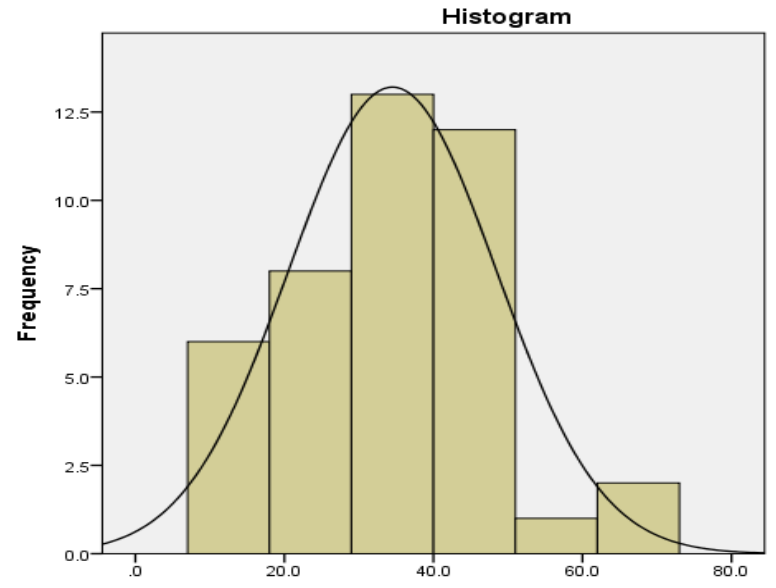

Gambar 3. Histogram gain skor dinormalisasi kompetensi pengetahuan IPA siswa kelompok control

Uji prasyarat dalam penelitian dilakukan sebagai syarat dipergunakannya statistik parametrik seperti penguji hipotesis dengan menggunakan uji-t. Uji prasyarat tersebut terdiri dari uji normalitas sebaran data dengan teknik kolmogorov-smirnov dan uji homogenitas varians dengan uji fisher $(\mathrm{F})$.

Berdasarkan hasil penghitungan tabel kerja uji normalitas sebaran data kelompok eksperimen diperoleh nilai $\left|\mathrm{F}_{\mathrm{T}}-\mathrm{Fs}\right|$ terbesar yaitu 0,106 . Nilai tersebut digunakan sebagai angka penguji normalitas sebaran data pada taraf signifikansi $5 \%$ untuk $n=34$ diperoleh nilai tabel kolmogorov-smirnov yaitu 0,227 sehingga perbandingan nilai $\mid \mathrm{F}_{\mathrm{T}}$-Fs $\mid$ terbesar < nilai tabel kolmogorov-smirnov yaitu 0,106 < 0,227, artinya sebaran data kelompok kelas eksperimen berdistribusi normal. Untuk kelas kontrol diperoleh nilai $\left|\mathrm{F}_{\mathrm{T}}-\mathrm{Fs}\right|$ terbesar yaitu 0,100 . Nilai tersebut digunakan sebagai angka penguji normalitas sebaran data pada taraf signifikansi $5 \%$ untuk $n=42$ diperoleh nilai tabel kolmogorov-smirnov yaitu 0,210 sehingga perbandingan nilai $\left|\mathrm{F}_{\mathrm{T}} \mathrm{Fs}\right|$ terbesar $<$ nilai tabel kolmogorov-smirnov yaitu $0,100<0,210$, artinya sebaran data kelompok kontrol berdistribusi normal.

Uji homogenitas dapat dilakukan apabila data berdistribusi normal. Uji homogenitas dilakukan untuk menunjukkan bahwa perbedaan yang diperoleh uji-t benar-benar berasal dari perbedaan antar kelompok bukan disebabkan oleh perbedaan di dalam kelompok. Untuk menguji homogenitas variansi kedua kelompok digunakan uji $\mathrm{F}$. Dari hasil perhitungan diperoleh $F_{\text {hitung }}=1,58$. Sedangkan $F_{\text {tabel }}=1,74$. Pada taraf signifikansi $5 \%(\alpha=0,05)$ dengan derajat kebebasan pembilang $34-1=33$ dan derajat kebebasan penyebut $42-1=41$. Maka nilai $F_{\text {hitung }}=1,58<F_{\text {tabel }}=1,74$ yang disimpulkan bahwa data kedua kelompok memiliki variansi yang homogen.

Data yang telah memenuhi uji prasyarat analisis selanjutnya dilakukan uji hipotesis menggunakan analisis statistik parametrik dengan uji-t polled varians. Adapun hipotesis yang akan diuji pada penelitian ini yaitu tidak terdapat perbedaan yang signifikan kompetensi 
pengetahuan IPA antara kelompok siswa yang dibelajarkan menggunakan model pembelajaran Visual Auditory Kinestethic bernuansa lingkungan dan kelompok siswa yang dibelajarkan menggunakan pembelajaran konvensional siswa kelas V SD Negeri Gugus Kolonel I Gusti Ngurah Rai Denpasar Utara Tahun Ajaran 2018/2019.

Hasil perhitungan uji-t diperoleh $t_{\text {hitung }}=5,448$, sedangkan nilai $t_{\text {tabel }}$ pada taraf signifikansi $5 \%$ dengan $\mathrm{dk}=\mathrm{n}_{1}+\mathrm{n}_{2}-2=34+42-2=74$ menunjukkan nilai tabel sebesar 2,000 . Sehingga diperoleh hasil analisis nilai $t_{\text {hitung }}=5,448>t_{\text {tabel }}=2,000$ maka $\mathrm{H}_{0}$ ditolak dan $\mathrm{H}_{\mathrm{a}}$ diterima. Hal ini menunjukkan terdapat perbedaan yang signifikan kompetensi pengetahuan IPA antara kelompok siswa yang dibelajarkan menggunakan model pembelajaran Visual Auditory Kinestethic bernuansa lingkungan dan kelompok siswa yang dibelajarkan menggunakan pembelajaran konvensional siswa kelas V SD Negeri Gugus Kolonel I Gusti Ngurah Rai Denpasar Utara Tahun Ajaran 2018/2019.

Perbedaan signifikan kompetensi pengetahuan IPA antara kelompok yang dibelajarkan menggunakan model pembelajaran Visual Auditory Kinestethic bernuansa lingkungan dan kelompok siswa yang dibelajarkan menggunakan pembelajaran konvensional dapat dilihat dari perbedaan hasil analisis statistik deskriptif kedua kelompok tersebut. Analisis statistik nilai pre test siswa diperoleh bahwa kedua kelompok kelas setara, setelah diberikan perlakukan berupa penerapan model pembelajaran Visual Auditory Kinestethic bernuansa lingkungan pada kelas eksperimen diperoleh perbedaan gain skor dinormalisasi kompetensi pengetahuan IPA siswa. Nilai gain skor dinormalisasi kompetensi pengetahuan IPA siswa pada kelompok eksperimen $\bar{X}=0,501$ lebih tinggi dari gain skor dinormalisasi kompetensi pengetahuan IPA siswa pada kelompok kontrol $\bar{X}=0,343$. Sehingga dapat disimpulkan bahwa terdapat pengaruh yang signifikan model pembelajaran Visual Auditory Kinestethic bernuansa lingkungan terhadap kompetensi pengetahuan IPA siswa kelas V SD Negeri Gugus Kolonel I Gusti Ngurah Rai Denpasar Utara Tahun Ajaran 2018/2019.

Kelompok eksperimen diberikan perlakuan berupa model pembelajaran Visual Auditory Kinestethic bernuansa lingkungan memiliki nilai rata-rata gain skor dinormalisasi yang lebih tinggi dibandingkan dengan kelompok kontrol yang menerapkan pembelajaran konvensional. Hal ini disebabkan karena model pembelajaran Visual Auditory Kinestethic merupakan suatu inovasi pembelajaran yang dapat menumbuhkan minat, motivasi, dan sikap percaya diri siswa dalam proses pembelajaran karena model pembelajaran ini mengkombinasikan tiga modalitas yang dimiliki oleh manusia yaitu penglihatan, pendengaran, dan gerakan tubuh. Ditambah lagi dalam proses pembelajaran yang dikombinasikan dengan lingkungan sebagai suasana belajar yang dapat memberikan pengalaman bermakna yang sulit untuk dilupakan oleh siswa. Dengan model pembelajaran Visual Auditory Kinestethic bernuansa lingkungan, pembelajaran menjadi lebih menarik dan menyenangkan serta dapat meningkatkan motivasi siswa karena dikemas dalam kegiatan pembelajaran yang meliputi kiat-kiat, petunjuk, strategi, dan seluruh proses belajar yang dapat mempertajam daya ingat, serta menjadikan belajar sebagai suatu proses yang menyenangkan, bermanfaat, dan bermakna. Dengan demikian siswa siswa lebih dapat memahami materi yang diberikan dan mengaplikasikan dalam kehidupan sehari-hari. Selain itu model pembelajaran Visual Auditory Kinestethic bernuansa lingkungan digunakan untuk pembelajaran, pemrosesan, dan komunikasi. Bahakan beberapa orang tidak cenderung kepada satu modalitas saja, namun bisa memanfaatkan kombinasi modalitas tertentu untuk meningkatkan kemampuan belajar. Visual auditory kinestethic merupakan tiga modalitas yang dimiliki oleh setiap manusia. Ketiga modalitas tersebut kemudian dikenal sebagai gaya belajar. Adapun kelebihan dari model pembelajarn Visual Auditory Kinestethic menurut Shoimin (2014:228) (a) Pembelajaran akan lebih efektif karena mengkombinasikan ketiga gaya belajar, (b) Mampu melatih dan mengembangkan potensi siswa yang telah dimiliki oleh pribadi masing-masing, (c) Memberikan pengalaman langsung kepada siswa, (d) Mampu melibatkan siswa secara maksimal dalam menemukan dan memahami suatu konsep melalui kegiatan fisik, seperti demonstrasi, percobaan, observasi, dan diskusi aktif, (e) Mampu menjangkau setiap gaya pembelajaran siswa, (f) Siswa yang memiliki kemampuan bagus tidak akan terhambat oleh siswa yang lemah dalam belajar karena model ini mampu melayani kebutuhan siswa yang memiliki kemampuan di atas rata-rata. Suryantini (2017) yang memperoleh data hasil 
kompetensi pengetahuan IPA siswa kelompok eksperimen lebih tinggi dari data hasil kompetensi pengetahuan IPA siswa kelompok kontrol.

\section{Simpulan dan Saran}

Berdasarkan hasil penelitian dan pembahasan dari analisis data dapat disimpulkan bahwa rata-rata nilai gain skor dinormalisasi kompetensi pengetahuan IPA kelompok siswa yang dibelajarkan menggunakan model pembelajaran Visual Auditory Kinestethic bernuansa lingkungan adalah 0,501 dengan nilai gain skor dinormalisasi tertinggi 0,71 dan nilai gain skor dinormalisasi terendah 0,29. Berdasarkan hasil penelitian dan pembahasan dari analisis data dapat disimpulkan bahwa nilai gain skor kompetensi pengetahuan IPA kelompok siswa yang dibelajarkan menggunakan pembelajaran konvensional adalah 0,343 dengan nilai gain skor dinormalisasi tertinggi 0,67 dan nilai gain skor dinormalisasi terendah 0,09.

Hasil analisis uji hipotesis menyatakan bahwa terdapat perbedaan yang signifikan nilai gain skor dinormalisasi dari kedua kelompok. Hal ini dibuktikan dengan analisis uji-t diperoleh $t_{\text {hitung }}=5,448$ sedangkan pada taraf signifikansi $5 \%$ dengan $\mathrm{dk}=74$ diperoleh nilai $t_{\text {tabel }}=2,000$. Karena $t_{\text {hitung }}=5,448>t_{\text {tabel }}=2,000$ maka $\mathrm{H}_{0}$ ditolak dan $\mathrm{H}_{\mathrm{a}}$ yang menyatakan terdapat perbedaan yang signifikan kompetensi pengetahuan IPA antara kelompok siswa yang dibelajarkan menggunakan model pembelajaran Visual Auditory Kinestethic bernuansa lingkungan dan kelompok siswa yang dibelajarkan menggunakan pembelajaran konvensional siswa kelas V SD Negeri Gugus Kolonel I Gusti Ngurah Rai Denpasar Utara Tahun Ajaran 2018/2019 diterima. Dari hasil analisis tersebut dapat disimpulkan bahwa terdapat perbedaan yang signifikan model pembelajaran Visual Auditory Kinestethic bernuansa lingkungan terhadap kompetensi pengetahuan IPA siswa kelas V SD Negeri Gugus Kolonel I Gusti Ngurah Rai Denpasar Utara Tahun Ajaran 2018/2019.

Berdasarkan temuan penelitian yang diperoleh, kepada guru disarankan lebih menambah wawasan dan pengetahuan tentang mengembangkan inovasi dan merancang pembelajaran untuk memberikan fasilitas berupa sumber belajar serta meningkatkan kualitas proses dan hasil pembelajaran dengan penerapan model pembelajaran Visual Auditory Kinestethic bernuansa lingkungan khususnya dalam pelajaran IPA dan mata pelajaran lain pada umumnya. Kepada kepala sekolah disarankan untuk dapat menggunakan hasil penelitian ini sebagai pendukung sumber belajar guru dalam meningkatkan pembelajaran sehingga dapat meningkatkan mutu dan kualitas serta proses pembelajaran yang efektif dan efisien. Kepada peneliti lain disarankan untuk menggunakan hasil penelitian ini sebagai acuan dalam melakukan penelitian selanjutnya pada tema dan kegiatan pembelajaran lainnya untuk memperoleh hasil yang lebih baik.

\section{Daftar Pustaka}

Agung, A. A. Gede. 2014. Metodelogi Penelitian Pendidikan. Malang: Aditya Media Publising

Ardiani, Ni Wyn. 2014. Model Brain Based Learning (BBL) Bernuansa Lingkungan Sekitar Berpengaruh Terhadap Kompetensi pengetahuan IPA Siswa Kelas V SD. Jurnal Mimbar PGSD Universitas Pendidikan Ganesha. Volume 2, Nomor 1.

Daryanto. 2014. Pendekatan Pembelajaran Saintifik Kurikulum 2013. Yogyakarta: Gava Media.

Huda, Miftahul. 2018. Model-model Pengajaran Dan Pembelajaran. Yogyakarta: Pustaka Pelajar.

Kardiyasa, I Komang. 2016. "Determinasi Kecenderungan Tipe Belajar Visual Auditory Kinestetik (VISUAL AUDITORY KINESTETHIC) Terhadap Sikap IImiah Pada Mata Pelajaran IPA Ditinjau Dari Jenis Kelamin Siswa Kelas V di Gugus I Kecamatan 
Buleleng Tahun Pelajaran 2015/2016”. e-Journal PGSD Universitas Pendidikan Ganesha Jurusan PGSD. Volume 4, Nomor 1.

Ngalimun. 2011. Strategi dan Model Pembelajaran. Yogyakarta: CV: Aswaja Pressindo.

Samatowa, usman. 2016. Pembelajaran IPA di Sekolah Dasar. Jakarta: PT.Indeks.

Sani, Ridwan Abdullah. 2014. Pembelajaran Saintifik untuk Implementasi Kurikulum 2013. Jakarta: PT Bumi Aksara.

Sanjaya, Wina. 2016. Strategi Pembelajaran Berorientasi Standar Proses Pendidikan. Jakarta: Prenadamedia Group.

Setiawan, Denny dkk. 2011. Komputer dan media pembelajaran. Jakarta: Universitas Terbuka

Shoimin, Aris. 2014. 68 Model Pembelajaran Inovatif Dalam Kurikulum 2013. Yogyakarta: AR-RUZZ MEDIA.

Sirait, Erlando Doni . 2016. Pengaruh Minat Belajar Terhadap Prestasi Belajar Matematika . Jurnal Formatif 6(1): 35-43, 2016

Soyomukti, Nurani. 2016. Teori-teori Pendidikan. Yogyakarta: Ar-Ruzz Media.

Sugiyono. 2017. Metode Penelitian Kuantitatif, Kualitatif, dan R \& D. Bandung: Alfabeta.

Suryantini, Ni Wayan Nanik. 2017. "Pengaruh Model Pembelajaran Visual Auditory Kinestetik Berbantuan Audio Visual Terhadap Kompetensi Pengetahuan IPA Kelas V. e-Journal PGSD Universitas Pendidikan Ganesha. Volume 5 Nomor 2.

Susanto, Ahmad. 2013. Teori Belajar dan Pembelajaran di Sekolah Dasar. Jakarta: PRANADAMEDIA GROUP.

Undang-undang Republik Indonesia Nomor 20 Tahun 2003 Tentang system Pendidikan Nasional

Uno, Hamzah B dan Nurdin Mohamad. 2012. Belajar dengan pendekatan PAILKEM. Jakarta: Bumi Aksara.

Wisudawati, Asih Widi dan Sulistyowati, Eka. 2015. Metodologi Pembelajaran IPA. Jakarta: PT Bumi Aksara.

Yusuf, Muri. 2015. Asesmen dan Evaluasi Pendidikan. Jakarta: Prenadamedia Grup. 